\title{
The body and truth: Intersecting discourses of Renaissance torture
}

\author{
Laura Marshall
}

\begin{abstract}
This essay was prepared for ENGL*4040 Medieval and Early Modern Literature under the
\end{abstract} supervision of Prof. Alan Shepard, School of English and Theatre Studies, College of Arts.

\begin{abstract}
From the 13th to the 17th century torture became a component of the judicial system, the goal of which was to discover the veracity of the accused. Two primary, competing discourses developed in order to explain the epistemological value of torture, the dicens veritatis and the dicens dubitatis. In the first discourse, torture exists as a producer of legitimate truth, while in the second the use of torture necessarily casts doubt on the obtained confession. This essay examines the ways in which the victim can undermine the torture process through the manipulation of these discourses. This is done within the dicens veritatis when the victim claims innocence and forces the torturer to accept this as truth. Within the dicens dubitatis, this is accomplished by forcing torturers to acknowledge the flawed nature of their own discourse through the telling of lies. The first component of my examination explores the transcripts of the legal proceedings against Domenico Scandella and Jean Bourdil, identifying the differing ways these victims employ both discourses to create a resistance to the torturer's predetermined narrative of events. The second component scrutinizes the depiction of the body within the philosophical writings of contemporary periods, thereby establishing the epistemological relationship between the body and pain. More broadly, my examination of literary, judicial and philosophical sources interrogates the justification of torture in the Early Modern period, allowing us to gain insight into the historical underpinning of modern sanctions of state-employed torture.
\end{abstract}

$I^{\mathrm{n}}$ a papal bull authorized by Pope Innocent in 1252, torture was introduced for the express purpose of obtaining a confession. The accused was first threatened with torture in the hopes that the threat itself might elicit a confession. If these initial threats failed, the accused was brought to the torture chamber and shown the instruments to be used. The torture chamber was designed to strike fear, horror, and despair into the hearts of those present. It was usually an underground residence lacking windows with only a few candles to light the room. The executioner was clothed entirely in black with the head and face covered, except for two eye-holes. Next the victim was stripped to the undergarments and his hands were bound together. The combination of darkness, an anonymous tormenter and the victim's own physical helplessness were designed to construct a setting that could resemble Hell, thus implicating the victim as the guilty party within the minds of the questioner and the victim himself. While the victim went through this demoralizing process, the questions put to him were repeated. If the accused still denied his guilt in the crime, the agony would begin. ${ }^{1}$

The goal of torture in the early modern period was to discover the truth. As such, two competing discourses of torture arise to uncover the truth, the dicens veritatis and the dicens dubitatis. ${ }^{2}$ The dicens veritatis was founded on the belief that the body was the route to uncovering truth. It was a common belief held by French officials that some truths were contained literally in the body and so only through torture could they be discovered. The act of torture then assumes that the truth is not readily available simply through the words of a speaker; rather the body must be examined in an effort to discover the truth contained within. This means that the body exists as a material reality in which the truth could reside and was susceptible to discovery. ${ }^{3}$ Torture, in this context, is a literal peeling back of the skin to discover the truth hidden in the flesh.

The French judicial system in the early modern period took this link between the body and truth one step further. One way in which torture was used to gain knowledge was through the reading of signs that could be coerced from the body. It was believed that the body could betray the accused criminal by displaying signs that could be seen while the will stopped the accused from speaking. Pallor was considered to be one such sign that implied guilty knowledge. Furthermore, the French believed that the truth was not only displayed on the surface of the body through signs such as pallor, but that it literally resided within the body. As a result, its revelation could only occur if it was torn from the body. Thus, the destruction of the body did not actually create a new truth, in that the speaker would give up a "truth" 
to avoid pain, but it allowed the torturer to make the victim an object rather than a subject of his own narrative truth. In this way, the torturer read the truth from victim's body rather than forcing him to reveal his own truth.

According to Lisa Silverman in Tortured Subjects: Pain, Truth, and the Body in Early Modern France, truth was a spontaneous production rather than a composed one and so by inflicting pain on the accused, one could destroy the willfulness that diminished the truth of testimony. ${ }^{4}$ Only by extracting a testimony that is not willed could pure truth be achieved. The torturer inflicted pain so that he could gain access to the spontaneous truth of the body rather than the composed truth of the mind. As Silverman says,

Only torture can satisfy the demand for the real truth, hidden in the flesh, perhaps unknown even to its possessor. Pain is, then, the vehicle of truth-telling, a distillation of the pure substance lodged in the impure flesh. Pain betrays the truth in the sense of exposing it to view through the sounds and gestures it produces. ${ }^{5}$

It is only the spontaneous truth produced through torture that could be considered the genuine truth sought after. The discourse that the torturer embraces when applying the instruments to the victim is a discourse founded on the notion that an objective truth could be reached by acting upon and reading the victim's body as an object that essentially silences the victim's ability to speak that truth.

On the other hand, the dicens dubitatis claims that truth obtained through torture is problematic and cannot be taken as the "real truth" of the torturer, but rather as a false truth. This discourse embodies what Timothy Reiss calls the analytico-referential discourse which "assumes that truth is an objective condition, external both to the mind that perceives it and to the language that describes it." ${ }^{, 6}$ Truth within this model then does not exist literally within the body, and so the pain of the body cannot be the route to genuine truth. In England during the Renaissance, for example, Catholics believed that torture was used to verify lies by forcing people to reveal treasons. This would further justify the government's repression of Catholicism. In their opinion, the torturer manufactured the truth they were struggling to uncover and so torture became a parody of the investigation leading to truth. ${ }^{7}$ This is the opposite of the French belief that torture merely revealed the truth hidden in the body.

Casare Beccaria, a philosopher condemning the use of torture in the eighteenth century, writes that torture leaves the victim with little freedom to do anything other than chose the quickest route to stop the pain. Due to this, the innocent man will admit guilt if it means that the pain will stop. ${ }^{8}$ This is the course that a thief named Juan Gomez in sixteenth century Italy takes during his torture session. Gomez was shown the instruments in an attempt to have him reveal of the location of stolen goods. During his torture he cries continually

\begin{abstract}
Ah, Signore, I don't know. Ah, Signore, I don't know. I don't know anything. Ah, Signore, ah, Signore, ah, if I don't know where they are, I can't tell you. God willing, and the Virgin Mary, if I knew I would tell. Ah, Lord Jesus Christ, I don't know ... Oh Signore, mercy, ah Signore, if I knew I would say. If your lordship wants me to say it, I will say it, but I don't know anything. ${ }^{\text {' }}$
\end{abstract}

In his testimony, he acknowledges that torture can produce a false truth. By saying "if your lordship wants me to say it, I will," he shows he is willing to lie in order to stop the pain.

The dicens dubitatis claims that torture produces false truth while the dicens veritatis claims only the destruction of the body can reveal truth. While these two views of torture conflict and it is the torturers themselves, acting with the weight of judicial authority, who appear to dictate the pattern of punishment and response, the victim can resist the torture through the manipulation of discourses. The victim does this either by operating within the dicens veritatis or by forcing the torturer to abandon his discourse and to operate within that of dubitatis. As Michel Foucault states in Discipline and Punish: The Birth of the Prison,

something of the joust survived, between the judge who ordered the judicial torture and the suspect who was tortured; the 'patient' - this is the term used to designate the victim - was subjected to a series of trials, graduated in severity, in which he succeeded if he 'held out', or failed if he confessed. ${ }^{10}$

These discourses found their grounding and expression in early modern jurisprudence and legal philosophy. Practically all European states used torture to obtain a confession of guilt in criminal trials throughout the early modern era. ${ }^{11} \mathrm{By}$ the seventeenth century, it was accepted as part of the criminal procedure throughout Europe. The actual committing of a crime was not the only reason for the enactment of this procedure; suspicion of participation in a crime constituted a sufficient reason to be tortured. Even if there was no other evidence to support an accusation, the person was liable to be put to the "question.," 2 Such questioning was used not only to determine the guilt or innocence of a suspected criminal, but it was also used in wide variety of cases from theft to treason to divulge the names of accomplices. More startling, however, is the fact that torture was also used on the witnesses of said crimes to confirm the truth of their statements. When two witnesses presented conflicting evidence both were tortured in the other's presence until an agreement of the evidence was achieved. ${ }^{13}$

In Italy, the state declared that only the worst crimes merited the use of torture to extract a confession. ${ }^{14} \mathrm{~A}$ series of statutes and laws existed to regulate the use of torture in the criminal justice system. These laws were only partially successful in regulating torture since many officials ignored such rules and applied the use of torture regardless. 
Furthermore, some officials had the authority to ignore the laws in cases involving gamblers, prostitution, thieves, and "any base persons committing any illegality." ${ }^{15}$ This shows the use of torture was wide spread, which meant that it could be used in almost all criminal cases. The laws to govern torture in Italy were lax compared with the strict laws of France.

The criminal system in France contained several ordinances to regulate the use of torture outlining when it could be used and to what extent. The Ordinance of Blois in 1579 states that a criminal could not be tortured repeatedly. New evidence must be presented to the court before torture could be used again. Furthermore, a report of the interrogation must be written and twenty-four hours after torture, and the victim had the right to confirm or deny the confession made under torture, this suggests the dicens dubitatis. This was done to avoid any false confessions as a result of the pain caused during the process. If the accused did not confess to being guilty under torture, he could not be given the death sentence, and those who continued to profess innocence under torture were to be set free without any criminal penalty. ${ }^{16}$ As shall be seen later, this practice was applied irregularly, and occasionally even if one continued to profess innocence he could still be condemned to a criminal penalty.

The Roman lawyer Azo in the thirteenth century defines torture as "the inquiry after truth by means of torment."17 The civil lawyer Bocer in the seventeenth century stated that "torture is interrogation by torment of the body, concerning a crime known to have occurred, legitimately ordered by a judge for the purpose of eliciting the truth about the said crime." ${ }^{, 18}$ From the thirteenth to the seventeenth century then torture became a component of the judicial system. However, from the late sixteenth century to the early eighteenth century there was little change in the practice and understanding of torture in western Europe.

The trials of Domenico Scandella, also called Menocchio, and Jean Bourdil represent cases where torture was employed as a means to obtain a confession. In both these cases, however, the victim resists the torture process by acting within the dicens veritatis or forcing the torturer to abandon his discourse and operate within the dicens dubitatis.

Menocchio was born in 1532 in Montereale, Italy. He earned his living as a "miller, carpenter, sawyer, mason, and other things" 19 but primarily as a miller. On September 28, 1583 he was denounced to the Church as having spoken heretical words about Jesus. He claimed that the world was created not through divinity, but what he called "the cheese and the worms." ${ }^{20}$ This was the first trial of many to come, each attempting to understand his cosmology and refute his beliefs, and attempting to discover from whom he had heard such ideas. After a lengthy interrogation without the use of torture, they set him free on the condition that he would not blaspheme again. He was arrested once again in July of 1599, sixteen years after his first arrest, on the same charge of heresy. On August 2 it was decided that Menocchio was "a convicted recidivist and should be considered as such, and that he should be tortured, not for the merits of his own case, but to extract the names of his accomplices and companions, with the understanding that he is to be considered a convicted criminal. ${ }^{21}$

On August 5 Menocchio was led to the torture chamber while being asked to give up the names of his accomplices. He maintained that he did not remember who he had talked to about his religious convictions. They prepared him for the strappado - a process in which one's hands were bound behind his back and then lifted into the air so that all the body's weight was borne on the shoulder joints ${ }^{22}$ - and they gave the first jerk on the rope. They repeated the question again, urging him to tell the truth, and he replied, "I would say it willingly, let me down and I'll think about it." 23 They lowered him, and after a moment he said that he still did not remember who he had spoken with. They ordered him to be given a second jerk on the strappado, and while being raised he cried to be let down again and that he would say something. Once lowered he said to them, "I spoke to signor Zuan Franceso Monatreale and told him we don't know what true faith is." ${ }^{24}$ That was all they could obtain from him through torture, so he was lowered and sent back to his cell. It was recorded that the torture was applied with moderation and had only lasted half an hour.

The Holy Office's desire to acquire the names of those he had spoken with proved to be fruitless in the end. Menocchio had only named one man that he had spoken with and that was the lord of Montereale. It seems that he had done this intentionally in an effort to deter the judges from digging too deeply. Eight times throughout the torture session he denied remembering who he had spoken with and after implicating the lord says that he has not spoken with anyone else. ${ }^{25}$ In addition to this, throughout his questioning on 12 July he was questioned and denied remembering who he had spoken with twelve times. ${ }^{26}$ This suggests that Menocchio was intentionally misleading the judges in his giving up the name of the lord of Montereale.

Menocchio resists the process of torture by playing to the dicens veritatis, that is, giving them exactly what they want to hear (naming names). Yet the name, or truth, that he provides is one that they cannot accept because he has implicated the lord of Montereale. Due to his association with the state it would be politically unwise to act on the implication. By doing this, Menocchio has trapped the judges in their own discourse because they must believe what they hear. Yet they cannot accept the truth offered to them through their own discourse because of the lord's position, so they are forced into the dicens dubitatis in which torture cannot produce the truth.

His resistance goes one step further when the following day he is asked to authorize that the words stated under torture were the truth. He signed that this was the case, but added in "that the above named signor Giovanni Francesco 
reprimanded me for my madness." 27 In the torture session he was an accomplice, but outside of torture he is not because he reprimanded Menocchio. He shows the flaw in the dicens veritatis because while technically it was the truth, Menocchio misrepresented it. So the judges had lost the 'joust' and Menocchio won by withholding the information they so desperately desired.

Menocchio forces the torturers to abandon their discourse and operate within the dicens dubitatis. Yet this does not save him and Menocchio is put to death. This is known from the depositions of Donato Serotino who told the commissioner of the inquisitor on July 6, 1601 that he had been in the Pordenone not long after "Scandella...had been executed by the order of the Holy Office." 28 So Menocchio's resistance was only partially successful. He had maintained that his ideas were his own, but he had not escaped the sentence of death.

The case of Jean Bourdil offers a different view of resistance to torture, but this is done by interacting within the dicens veritatis rather than forcing the torturer into the dicens dubitatis. On the night of April 17, 1726, two men were killed near Pont Neuf in France. The captain of the guard arrested Louis Prieur and Jean Bourdil, an archer, for suspicion of murder. Thirteen witnesses came forward in relation to the murder, but the evidence they produced conflicted. Some claimed that Bourdil was certainly among the group who attacked the men, some claimed he was not, and others could not be sure. The testimony of the witnesses was inconclusive yet no one had seen him actually attack any of the men.

Since there was not adequate evidence to condemn either of the accused to death it was decided that there was enough evidence to warrant torture. It was recorded in the report that

before passing judgment definitely...it should be ordered that the named Jean Bourdil called Police, one of the accused, should be, reserving the proofs and evidence of the whole trial, applied to the ordinary and extraordinary question in order to know the truth from his own mouth, if he did not commit the said murders, and his accomplices, and with regard to Louis Prieur, also accused, it should be ordered that judgment will be suspended in his case until the report of the process-verbal of the question. ${ }^{29}$

Yet before Bourdil underwent this torture, he and Louis were questioned again and a sentence was passed on the two. It was decided that Bourdil was guilty of the murders and should be condemned to death by breaking on the wheel and that Louis Prieur should be released. This initial sentence was held until the review of the accused's appeal leaving Bourdil with a chance to prove his innocence. ${ }^{30}$

The higher court ruled that the lack of evidence was not enough to condemn Bourdil to death, and so he was to be put to the question in order to gain more evidence. On May 25, 1726 he was put to the question ordinaire three times and once on May 27. This was in the form of the estrapade, the same process as the strappado that Menocchio experienced. Following this, he was put to the question extraordinaire five times in the form of the question d'eau. This form of questioning involved Bourdil's body being extended to its full length at a slant and trestles of varying heights being wedged under his back, forcing a further extension of the body. Then his face was covered with a linen cloth and water was forced down his throat through a cow's horn, sixteen liters at a time. ${ }^{31}$

During such torment he was continually asked to tell the truth of whether he is guilty of the murders, if he is an accomplice, or knows who the guilty party is. Bourdil insisted on his innocence and answered that "he told the truth and that he is innocence of the murder of the said two soldiers, and that he knows neither the murderers, nor the accomplices." 32 He also never specified any knowledge of the crime that only the guilty would know. Twenty-four hours later the transcript of the interrogation was read aloud, and Bourdil was made to sign it to authorize that he had spoken those words.

Throughout the two sessions of torture, Bourdil had maintained his innocence of the crime and did not bring forward any new evidence for the case. On June 6, 1726, the final sentence was made on Bourdil and Prieur. Prieur was set free without any criminal charges and Bourdil was sentenced to life in the galleys, a life of forced labour, for his supposed crimes. ${ }^{33}$ The torture served its intended purpose, and as Foucault puts it "the suspect was not declared innocent by his resistance; but at the very least his victory saved him from being condemned to death.",34

While the torture served its intended purpose, Bourdil resisted the process of torture by maintaining he was innocent of the murders. Bourdil acts within the dicens veritatis by forcing his torturers to accept that he is telling the truth about his innocence. In this case the torturer believes that torture produces legitimate truth and therefore the court overturned his death sentence because he must be innocent after having claimed that in the torture chamber. The rule of the joust was "that if the accused 'held out' and did not confess, the magistrate was forced to drop the charges. The tortured man had won." 35 His resistance exists because they want him to confess his guilt, but instead he maintains his innocence, forcing them to accept his truth.

The discourse Bourdil creates is successful in a way that Menocchio's is not because his discourse is able to save his life. Yet like Menocchio, his discourse is only partially successful because, whereas the law says that a confession of innocence under torture requires one to be set free with no criminal penalty, Bourdil is still sentenced to pay for his crimes.

There was little change in the attitudes toward torture between the trials and tortures of Menocchio and Bourdil. From 1500 to 1750 torture had both critics and defenders and much of the legal literature and legislation surrounding it was aimed at correcting known abuses in the system and rarely 
ending in the abolishment of the system itself. ${ }^{36}$ It was from the years 1760 to 1840 that the use of torture began a transformation, thirty four years after Bourdil's death. ${ }^{37}$ Beccaria's treatise On Crimes and Punishments, is perhaps the best-known attack on the use of tortures in criminal cases published and was only published in 1764. In France in 1766 Louis XVI abolished torture for the purpose of obtaining and confession and in 1788 abolished torture applied after conviction to obtain the names of accomplices. ${ }^{38}$

While there were critics during both times, it is not until thirty four years after Bourdil's death that the critics were taken seriously. Such an attitude change can be found in the case of the torture of Jean Calas in 1762, thirty six years after Bourdil. Calas was convicted and found guilty for the murder of his eldest son. After his execution, his youngest son went to Geneva to get support from Voltaire to clear his family's name. Calas' case 'became an international cause célèbre, a challenge to the justice system and to its methods." 39 Like Bourdil, Calas denied guilt and was sentenced to death despite his protestations of innocence; yet no one came to Bourdil's defense. Consequently, in the intervening thirty six years, the meaning and function of torture changed and by the beginning of the nineteenth century torture was abolished in virtually all of western Europe.

The trials and ordeals of Menocchio and Bourdil illustrate two ways in which one can resist the torture process. The first is to operate within the dicens veritatis - with torture as a producer of legitimate truth - and the second is to force the torturer to abandon his discourse and operate within the dicens dubitatis - with torture as a producer of false truth. This is done within the veritatis discourse by claiming innocence and forcing the torturer to accept this truth and within the dubitatis by forcing the torture to acknowledge the flawed nature of their own discourse and thereby forcing them to function within the victim's through the telling of lies.

It is the torturer rather than the victim then that must decide in which discourse to operate. Menocchio and Bourdil both undermine the torture process, one by claiming innocence (Bourdil) and the other by giving his torturers exactly want they want, but a truth that they cannot accept (Menocchio). The difference is that in Bourdil's case the judges believed that torture produces legitimate truth, and therefore they overturned his death sentence because he must have been innocent after having claimed to be so in the torture chamber. In Menocchio's case, the miller gives them exactly what they want to hear (who he has spoken with) yet it is a truth that they cannot accept because he gives them the name of the lord of Montereale. The torturers become trapped within their discourse because they have to believe what they hear. Consequently, they buy into the idea of torture as a producer of false truth because they cannot accept what their own discourse has produced. Therefore, they can say that Menocchio can still be condemned to death, while Bourdil escapes it.
The case of Juan Gomez, the thief who was tortured to give up the location of stolen goods, presents a different situation in which torture was used. During his torture session he says, "If your lordship wants me to say [the location], I will say it, but I don't know anything." 40 Through this statement he points out that the process of torture is flawed because he does not have the information they are looking for - a truth to be uncovered. Gomez does not offer resistance to the process because he does not lie like Menocchio did nor is he attempting to prove his innocence. Thus he is free from both the dicens veritatis and the dicens dubitatis because he exists in a world where there is no truth to discover. While Menocchio and Bourdil resist the torture process by acting within their own discourses, Gomez's resistance is in his attack on the process as flawed when there is no truth to be found.

According to Silverman, "torture testified both to the meaningfulness of human suffering and the corresponding valuelessness of human volition, and to the intimate connections among pain, truth, and the body."41 This link between the three is what creates the complex process of torture as a means of extracting a confession. The dicens veritatis and the dicens dubitatis exist within the process to question the legitimacy of the truths produced within their discourse. Furthermore, resistance can occur within both discourses by claiming innocence as Bourdil does or telling lies like Menocchio to force the torturer into the dicens dubitatis. While these discourses illustrate the complexity of the link between torture and truth, the case of Juan Gomez further complicates the process. It acts as an example of the inherently flawed nature of torture because the truth is not always available to be found either in the body or outside of it.

\section{ENDNOTES}

${ }^{1}$ George Ryley Scott, The History of Torture Throughout the Ages (London: Kegan Paul Limited, 2003), 66-67.

2 The terms dicens veritatis and dicens dubitatis are used to represent different kinds of truth. Dicens veritatis is a truth that can be guaranteed and legitimized by the pain of the body while dicens dubitatis suggests that truth cannot be absolutely guaranteed by pain.

3 Mary Phillips, "Recusant Confessions and the (En)Gendering of Disclosure," Critical Survey 11.1 (1999):76.

${ }^{4}$ Silverman, 9.

${ }^{5}$ Silverman, 63.

6 Elizabeth Hanson, "Torture and Truth in Renaissance England," Representations 34 (Spring, 1991): 54.

${ }^{7}$ Hanson, 55. 
${ }^{8}$ Cesare Beccaria, On Crimes and Punishments and Other Writings, ed. Richard Bellamy, trans. Richard Davies (Cambridge: Cambridge University Press, 1995), 41.

${ }^{9}$ Cohen, 990.

${ }^{10}$ Michel Foucault, Discipline and Punish: The Birth of the Prison, trans. Alan Sheridan (New York: Vintage Books, 1979), 40.

11 Confession was elevated to the top of the hierarchy of proof and was called the "Queen of Proofs." This elevation arose from sacramental confession being made an annual obligation by the Fourth Lateran Council of 1215 and thereby becoming one of the two principal arenas of cannon law (the other being the cannon law trial itself) as is seen in Edward Peters, Torture (New York: Basil Blackwell, 1985), $41 \& 47$.

${ }^{12} \mathrm{Scott}, 62$.

13 Scott, 62.

14 Thomas V. Cohen, "Three Forms of Jeopardy: Honor, Pain, and Truth-Telling in a Sixteenth-Century Italian Courtroom," Sixteenth Century Journal 29.4 (1998): 990.

${ }^{15}$ Trevor Dean, "Criminal Justice in Mid-Fifteenth-Century Bologna," Crime, Society, and the Law in Renaissance Italy, ed. Trevor Dean and K.J.P. Lowe (Cambridge: Cambridge University Press, 1994), 21.

${ }^{16}$ Lisa Silverman, Tortured Subjects: Pain, Truth, and the Body in Early Modern France (Chicago: University of Chicago Press, 2001), 42.

17 Edward Peters, Torture (New York: Basil Blackwell, 1985), 1.

${ }^{18}$ Peters, 1.

${ }^{19}$ Carlo Ginzburg, The Cheese and the Worms: The Cosmos of a Sixteenth-Century Miller, trans. John and Anne Tedeschi (Baltimore: Johns Hopkins University Press, 1992), 1.

${ }^{20}$ Ginzburg, 57. The cheese and the worms cosmology of Menocchio was originally intended as an analogy to explain his belief that the angels were created from spontaneous generation "without resorting to divine intervention."

21 Andrea Del Col, Domenico Scandella Known as Menocchio: His Trials Before the Inquisition (1583-1599), trans. John \& Anne C. Tedeschi (Binghamton: Center for Medieval and Early Renaissance Studies State University of New York, 1996), 152.

${ }^{22}$ Silverman, 46.

${ }^{23}$ Ginzburg, 111.

${ }^{24}$ Ginzburg, 111.

${ }^{25}$ Del Col, 155.

${ }^{26}$ Del Col, 127-134.

${ }^{27}$ Del Col, 155.

${ }^{28}$ Ginzburg, 128.

${ }^{29}$ Silverman, 36.

${ }^{30}$ Silverman, 37.

${ }^{31}$ Silverman, 46.
${ }^{32}$ Silverman, 47.

${ }^{33}$ Silverman, 48.

${ }^{34}$ Foucault, 41.

${ }^{35}$ Foucault, 41.

${ }^{36}$ Peters, $69 \& 72$.

${ }^{37}$ Foucault, 15.

${ }^{38}$ Peters, 73.

${ }^{39}$ Silverman, 3.

${ }^{40}$ Cohen, 990.

${ }^{41}$ Silverman, 8.

\section{REFERENCES}

Abbott, G. Tortures of the Tower of London. London: A. Wheaton \& Co Ltd, 1986.

Beccaria, Cesare. On Crimes and Punishments and Other Writings. Ed. Richard Bellamy. Trans. Richard Davies. Cambridge: Cambridge University Press, 1995.

Biller, Pether and A. J. Minnis, eds. Handling Sin Confession in the Middle Ages. York: York Medieval Press, 1998.

Cohen, Thomas V. "Three Forms of Jeopardy: Honor, Pain, and Truth-Telling in a Sixteenth-Century Italian Courtroom." Sixteenth Century Journal 29.4 (1998): 975998.

Dean, Trevor. "Criminal Justice in Mid-Fifteenth-Century Bologna." Crime, Society, and the Law in Renaissance Italy. Ed. Trevor Dean and K.J.P. Lowe. Cambridge: Cambridge University Press, 1994.

Del Col, Andrea. Domenico Scandella Known as Menocchio: His Trials Before the Inquisition (1583-1599). Trans. John and Anne C. Tedeschi. Binghamton: Center for Medieval and Early Renaissance Studies State University of New York, 1996.

Foucault, Michel. Discipline and Punish: The Birth of the Prison. Trans. Alan Sheridan. New York: Vintage Books, 1979.

Ginzburg, Carlo. The Cheese and the Worms: The Cosmos of a Sixteenth-Century Miller. Trans. John and Anne Tedeschi. Baltimore: Johns Hopkins University Press, 1992.

Hanson, Elizabeth. "Torture and Truth in Renaissance England." Representations 34 (Spring, 1991): 53-84.

Heath, James. Torture and English Law: An Administrative and Legal History from the Plantagenets to the Stuarts. London: Greenwood Press, 1982.

Little, Katherine C. Confession and Resistance Defining the self in Late Medieval England. Notre Dame: University of Notre Dame Press, 2006.

Merback, Mitchell B. The Thief, the Cross, and the Wheel: Pain and the Spectacle of Punishment in Medieval and Renaissance Europe. London: University of Chicago Press, 1998. 
Parry, L.A. The History of Torture in England. Montclair: Patterson Smith, 1975.

Peters, Edward. Torture. New York: Basil Blackwell, 1985.

Phillips, Mary. "Recusant Confessions and the (En)Gendering of Disclosure." Critical Survey 11.1 (1999): 66-82.

Rubin, Miri. "The Body, Whole and Vulnerable, in Fifteenth-Century England." Bodies and Disciplines: Intersections of Literature and History in FifteenthCentury England. Medieval Cultures. Ed. Barbara A. Hanawalt and David Wallace. Vol. 9. Minneapolis: University of Minnesota Press, 1996.

Scott, George Ryley. The History of Torture Throughout the Ages. London: Kegan Paul Limited, 2003.

Silverman, Lisa. Tortured Subjects: Pain, Truth, and the Body in Early Modern France. Chicago: University of Chicago Press, 2001. 